\title{
Silicon-containing dendritic tris-cyclometalated Ir(III) complex and its electrophosphorescence in a polymer host
}

\author{
Youngmin You, ${ }^{a}$ Cheng-Guo An, ${ }^{a}$ Deug-Sang Lee, ${ }^{b}$ Jang-Joo Kim ${ }^{a}$ and Soo Young Park*a \\ Received 4th August 2006, Accepted 3rd October 2006 \\ First published as an Advance Article on the web 25th October 2006 \\ DOI: $10.1039 / \mathrm{b} 611288 \mathrm{a}$
}

In this paper, we present the synthesis and characterization of a new highly phosphorescent cyclometalated Ir(III) complex with a silane-based dendritic substituent. $\operatorname{The} \operatorname{Ir}(\mathrm{III})$ complex showed $74 \pm 3 \%$ of absolute phosphorescence quantum efficiency in the film state. In addition, efficient electrophosphorescence (32.8 $\mathrm{cd} \mathrm{A}^{-1}$ ) employing an $\operatorname{Ir}(\mathrm{III})$ complex-

poly $(N$-vinylcarbazole) system device is observed. Study of a series of electroluminescent, spectroscopic, and electrochemical data of the $\operatorname{Ir}(\mathrm{III})$ complex and the reference $\operatorname{Ir}(\mathrm{ppy})_{3}$ reveals superior performance of the new Ir(III) complex.

\section{Introduction}

Since the pioneering works of Forrest and coworkers, electrophosphorescence from transition metal complexes has attracted ever increasing attention due to the potential applications of such complexes in organic light emitting diodes (OLEDs). ${ }^{1,2}$ The highly efficient intersystem crossing induced by the core metal in transition metal complexes makes it possible to utilize the luminescent triplet exciton in addition to the singlet exciton to achieve an internal quantum efficiency of $100 \%$, which is far superior to the internal quantum efficiency up to $25 \%$ that is typically recognized as the higher limit in fluorescence-based OLEDs. Among the phosphorescent transition metal complexes studied to date, $\operatorname{Ir}(\mathrm{III})$ complexes are currently receiving special attention because they exhibit the highest phosphorescence quantum efficiencies, relatively short phosphorescence lifetime, and facile color tuning by modification of the ligand structures. ${ }^{3-6}$

Ir(III) complex-based OLEDs are typically fabricated in a configuration in which the emissive layer is comprised of the phosphorescent $\operatorname{Ir}$ (III) complexes doped in a small-molecular or polymeric host. The efficiency of devices based on these host-guest systems is normally limited by phase segregation, ${ }^{7}$ triplet-triplet annihilation, ${ }^{8}$ excimer formation, ${ }^{9}$ and other excited-state intermolecular interactions, all of which become more significant as the concentration of emitting dopants is increased. Thus, to maximize the device efficiency, it is necessary to carry out laborious optimization procedures to optimize the doping ratio and to find the host material that is most compatible with the specific Ir(III) complex. In this regard, new $\operatorname{Ir}(\mathrm{III})$ complexes that are unaffected by these undesirable excited-state intermolecular interactions are in strong demand.

One promising solution is to provide 'site-isolation' by employing a dendritic architecture in the peripheral surface of

\footnotetext{
${ }^{a}$ School of Materials Science \& Engineering, Seoul National University, San 56-1, Shillim-Dong, Kwanak-Gu, Seoul 151-744, Korea.

E-mail: parksy@snu.ac.kr; Fax: +82-2-886-8331; Tel: +82-2-880-7479

${ }^{b}$ Central R\&D center, Dongwoo FineChem Co., Ltd. 1177, PyungtaekSi, Kyunggi-Do, 451-764, Korea
}

the coordination environment of the emission center. ${ }^{10-12}$ The Burn and Samuel group developed a series of dendritic Ir(III) complexes in this manner. They established that encapsulation of emissive tris-cyclometalated Ir(III) complexes with ethylhexyloxy-terminated meta-terphenyl type dendrons successfully controlled the intermolecular interactions, thereby enhancing the phosphorescence efficiency. OLEDs based on dendritic Ir(III) complexes of this type gave a luminous efficiency of $55 \mathrm{~cd} \mathrm{~A}^{-1}$ at $4.5 \mathrm{~V}$ for green emission, ${ }^{13}$ an external quantum efficiency of $10.4 \%$ at $6.4 \mathrm{~V}$ for blue emission, ${ }^{14}$ and an external quantum efficiency of $5.7 \%$ at a luminance of $80 \mathrm{~cd} \mathrm{~m}^{-2}$ for red emission. ${ }^{15}$ In addition to these high device efficiencies, the sterically congested structure as well as the terminal alkyl group of the dendritic $\operatorname{Ir}(\mathrm{III})$ complex offered much improved solubility in common polar organic solvents enabling easier device fabrication via spin coating. A similar dendritic approach employing the pinene group also showed a high luminous efficiency of $10.5 \mathrm{~cd} \mathrm{~A}^{-1}$ at $6 \mathrm{~V} .^{16}$ However, although the peripheral alkyl moieties (ethylhexyloxy and pinene functionalities) are beneficial in terms of reducing interactions, they create an insulating periphery that leads to reduced current characteristics with increasing dendrimer generation. This is evident in the observation that the first generation of the tris-cyclometalated $\operatorname{Ir}($ III) complexes with six ethylhexyloxy-terminated meta-terphenyl dendrons gave inferior luminous efficiency (47 $\mathrm{cd} \mathrm{A}^{-1}$ at $4.8 \mathrm{~V}$ ) compared to that $\left(55 \mathrm{~cd} \mathrm{~A}^{-1}\right.$ at $\left.4.5 \mathrm{~V}\right)$ of the first generation of the $\operatorname{Ir}(\mathrm{III})$ complex with three identical dendrons. ${ }^{13,17}$ Although these device efficiencies are sufficient for device application, the opposing effects of a dendritic architecture on device efficiency indicate that high dendrimer generation is not the sole structural requirement for high device efficiency. Thus, a novel dendritic substituent with the optimized (compromised between encapsulation and current characteristics) structure is needed.

Previous studies have shown that arylsilanes such as the triphenylsilyl group provide sufficient steric hindrance to protect typical reactive centers. We therefore hypothesized that the tetrahedral configuration of aryl rings around the silicon atom may provide a similar 'site-isolation' effect if 
applied as the ligand substituents of the Ir(III) complex. In addition, the highly efficient UV emission of arylsilanes suggests that these moieties should give improved efficiency compared to alkyl substituents in OLED applications. ${ }^{18,19}$ Moreover, the silane moieties are expected to provide high thermal and chemical stability as well as glassy properties when incorporated into $\operatorname{Ir}(\mathrm{III})$ complexes. ${ }^{20}$ In this paper, we describe the design and synthesis of a highly phosphorescent tris-cyclometalated homoleptic $\operatorname{Ir}(\mathrm{III})$ complex [Ir(TPSppy $\left.)_{3}\right]$ (TPSppy $=2-\left(4^{\prime}\right.$-(triphenylsilyl) biphenyl-3-yl)pyridine $)$ with a silane-based dendritic substituent. We show that a conventional polymer-based [poly( $N$-vinyl carbazole), PVK] OLED doped with this $\operatorname{Ir}(\mathrm{III})$ complex has an unprecedentedly high device efficiency $\left(32.8 \mathrm{~cd} \mathrm{~A}^{-1}\right)$.

\section{Results and discussion}

As depicted in Scheme 1, the dendritic arylsilane group in the cyclometalating ligand (1) was introduced by a SuzukiMiyaura coupling reaction of 4-triphenylsilylphenylboronic acid and 2-(3-bromophenyl)pyridine. Nonoyama reaction of this cyclometalating ligand (1) and $\operatorname{Ir}(\mathrm{III})$ chloride hydrate gave the $\mu$-chloride-bridged dimer in good yield, which was subsequently chelated with $\mathbf{1}$ in glycerol, affording the triscyclometalated homoleptic $\operatorname{Ir}(\mathrm{III})$ complex, $\operatorname{Ir}(\mathrm{TPSppy})_{3}$, in moderate yield. Both Ir(TPSppy $)_{3}$ and the $\mu$-chloride-bridged dimer showed excellent solubility in a variety of common organic solvents, demonstrating that the dendritic substituent operated in the coordination environment of the $\operatorname{Ir}(\mathrm{III})$ complex. On the other hand, $\operatorname{Ir}\left(\right.$ ppy) ${ }_{3}$ (ppy $=2$-phenylpyridine), the well-known reference material without dendritic substituents, exhibited relatively poor solubility. From this observation, it was initially anticipated that the severe phase segregation observed in $\operatorname{Ir}(\mathrm{ppy})_{3}-\mathrm{PVK}$ films ${ }^{21}$ would be significantly reduced in $\operatorname{Ir}(\mathrm{TPSppy})_{3}-\mathrm{PVK}$ films, thereby suppressing the formation of unfavorable low energy traps in OLED devices based on such films.

In the UV-vis absorption spectrum of $\operatorname{Ir}(\text { TPSppy) })_{3}$ (Fig. 1), the metal-to-ligand charge-transfer (MLCT) transition was observed in the region of $370-520 \mathrm{~nm}$ along with the ligandcentered $\pi \rightarrow \pi^{*}$ transitions at $296 \mathrm{~nm}$ and $335 \mathrm{~nm} .^{22}$ The spectral shape was similar to that observed for $\operatorname{Ir}(\mathrm{ppy})_{3}$ except that the spectrum of $\operatorname{Ir}(\text { TPSppy })_{3}$ contains an additional transition at lower energy (longer than $470 \mathrm{~nm}$ ), which can be attributed to the extension of the conjugation due to the additional phenyl ring in the phenylpyridine unit of the cyclometalating ligand (1). Strong phosphorescent emission of $\operatorname{Ir}(\text { TPSppy })_{3}$ in solution $\left(1 \times 10^{-5} \mathrm{M}\right.$ in PhMe $)$ as well as in a doped film [3 wt $\% \operatorname{Ir}(\text { TPSppy) })_{3}$ in poly(methyl methacrylate) (PMMA)] was observed at $531 \mathrm{~nm}$ and $533 \mathrm{~nm}$, respectively (see Table 1). These emission maxima were bathochromically shifted compared to the corresponding values for $\operatorname{Ir}(p p y)_{3}$, $517 \mathrm{~nm}$ for $1 \times 10^{-5} \mathrm{M}$ in $\mathrm{PhMe}$ and $515 \mathrm{~nm}$ for $3 \mathrm{wt} \%$ in PMMA film. Again, this red-shift is attributed to the additional phenyl ring in the cyclometalating ligand. It is noted, however, that the spectra of $\operatorname{Ir}(\text { TPSppy })_{3}$ and $\operatorname{Ir}(\text { ppy })_{3}$ have virtually identical shapes, indicating that the same excited and/or ground states were involved in the phosphorescent transitions. In contrast, the dendron part of the triphenylsilyl group seems to have a negligible effect on the shift of emission maxima, which is further supported by the results of density functional theory (DFT) calculations. As shown in Fig. 2, the distribution of the highest occupied molecular orbital (HOMO) and the lowest unoccupied molecular orbital (LUMO) of $\operatorname{Ir}($ TPSppy) 3 clearly demonstrates the shielding effect of the dendritic substituent. The HOMO is located over the d-orbital of Ir and the biphenyl moiety of the cyclometalating group, whereas the LUMO is located over the pyridine ring. In contrast, the triphenylsilyl dendron exhibits a nearly zero probability of electronic population in the frontier orbitals. Such negligible effect of the triphenylsilyl dendron on the transition in $\operatorname{Ir}\left(\right.$ TPSppy) ${ }_{3}$ was also evident in the results of electrochemical measurements. A voltage scan in the range of $1.6 \mathrm{~V}$ to $-1.5 \mathrm{~V}$ (relative to a $\mathrm{Ag} / \mathrm{Ag}^{+}$pseudo-reference electrode) for the $\operatorname{Ir}(\text { TPSppy })_{3}$ and $\operatorname{Ir}(\mathrm{ppy})_{3}$ solutions containing tetrabutylammonium tetrafluoroborate as a supporting electrolyte showed oxidation at $0.91 \mathrm{~V}$ and $0.96 \mathrm{~V}$, respectively. Given the small difference in oxidation potential for $\operatorname{Ir}(\text { TPSppy })_{3}$ and $\operatorname{Ir}(\text { ppy })_{3}$, and the fact that the addition of a phenyl ring in the cyclometalating ligand would be expected to change the oxidation potential, the electrochemical findings suggest that the presence of the arylsilane substituents does not notably alter the HOMO energy. Collectively, the results indicate that the triphenylsilyl dendritic substituent plays a key role in shielding the emission center against undesirable nonradiative pathways, without changing the inherent emissive transition of $\operatorname{Ir}(\mathrm{ppy})_{3}$.

Comparison of the shift in the photoluminescence peaks of $\operatorname{Ir}(\text { TPSppy })_{3}$ in the solution $(531 \mathrm{~nm})$ and film $(533 \mathrm{~nm})$ states suggests that the degree of charge-transfer transition (MLCT) is relatively small, ensuring that various host materials with different polarities can be used without altering the emission characteristics. Both solution and solid states of $\operatorname{Ir}(\text { TPSppy })_{3}$ were highly phosphorescent; the solution phosphorescence quantum yield of $\operatorname{Ir}(\text { TPSppy })_{3}$ in the Ar-saturated $\mathrm{PhMe}$ solution was 0.63 , which is higher than that of $\operatorname{Ir}(\mathrm{ppy})_{3}(0.40)$, and the absolute phosphorescence quantum yield of the film of $\operatorname{Ir}(\text { TPSppy) })_{3}$ was also surprisingly high, reaching $74 \pm 3 \%$. These high values can be attributed to the dendritic architecture, which effectively blocks the non-emissive pathways provided by various intermolecular excited-state interactions.

PVK-based OLEDs with the typical configuration of ITO/PSS : PEDOT/PVK : $\mathrm{Ir}(\mathrm{III})$ complex/BCP/Alq $3 / \mathrm{LiF} / \mathrm{Al}[\mathrm{ITO}=$ indium tin oxide, $\mathrm{PSS}=\operatorname{poly}($ styrene sulfonic $\mathrm{acid}), \mathrm{PEDOT}=\operatorname{poly}(3,4-$ ethylenedioxythiophene), BCP = 2,9-dimethyl-4,7-diphenyl-1,10phenanthroline, $\mathrm{Alq}_{3}=\operatorname{tris}(8$-hydroxyquinolinolato $\left.)\right]$ were fabricated. To investigate the effect of guest concentration, the doping ratio of $\mathrm{Ir}$ (III) complex in PVK was varied from 0.5 to $30 \mathrm{wt} \%$. Within this range of doping ratios, we could find the optimum device efficiency (see Table 2). As shown in Fig. 3, none of the electroluminescence spectra of the OLEDs displayed excimer emission at longer wavelengths, indicating that the dendritic substituent in $\operatorname{Ir}(\text { TPSppy) })_{3}$ frustrated the inter-chromophoric interactions at all of the doping ratios tested $(0.5-30 \mathrm{wt} \%) .{ }^{9}$ In addition, the OLED emission characteristics showed no voltage dependence indicating that these OLEDs will give stable emission over long term operation. The peak wavelength in the 


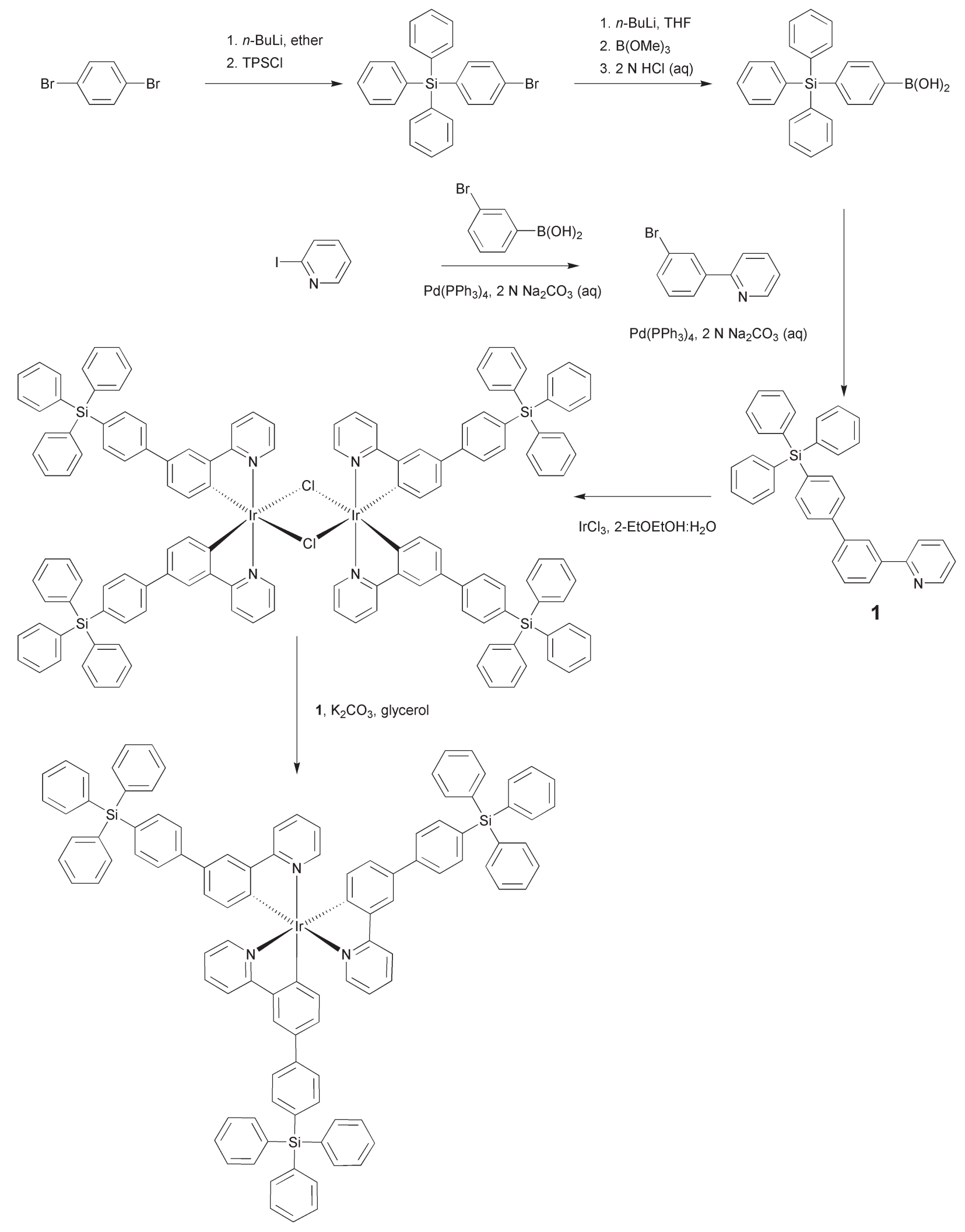

Scheme 1 Synthesis of the $\operatorname{Ir}(\mathrm{III})$ complex (Ir(TPSppy) $)_{3}$.

electroluminescence spectra was $524 \mathrm{~nm}$, which was slightly blueshifted with respect to that $(531 \mathrm{~nm})$ of the photoluminescence spectra. The small shoulder at $450 \mathrm{~nm}$ observed in the electroluminescence spectrum of the $0.5 \mathrm{wt} \%$ device is attributed to exciplex formation between the host (PVK) and hole-blocking BCP originating from redundant excitons that could not be trapped by the Ir(III) complex. ${ }^{23}$ This small exciplex band was not observed in the spectra of OLEDs with doping ratios of $1 \mathrm{wt} \%$ and 

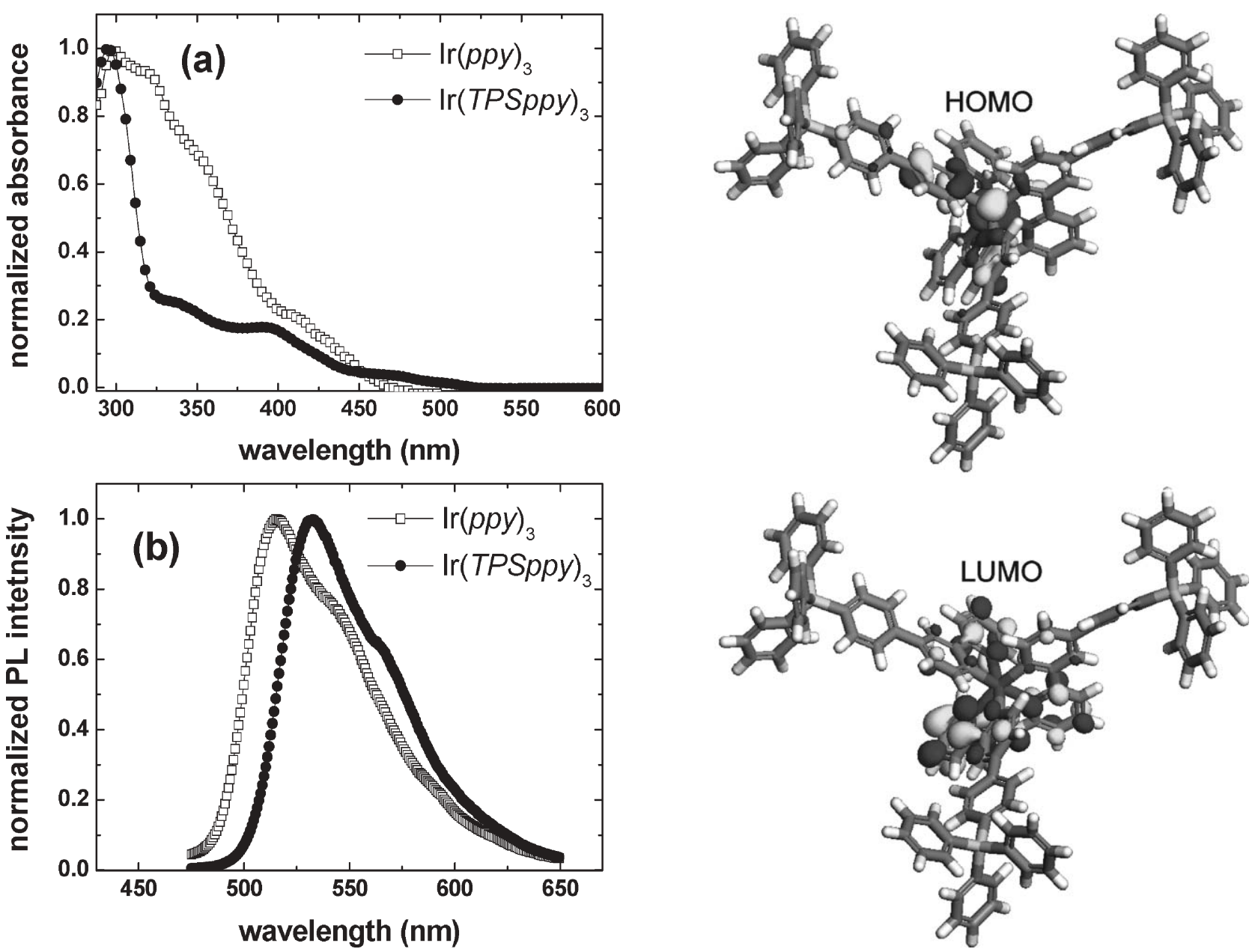

Fig. 1 UV-vis absorption (a) and photoluminescence (b) spectra of $\operatorname{Ir}(\text { TPSppy })_{3}$ and the reference $\operatorname{Ir}(\text { ppy })_{3}$ in the solution state $(1.0 \times$

Fig. 2 Calculated contour plots of frontier orbitals of $\operatorname{Ir}(\mathrm{TPS} p \mathrm{P})_{3}$. $10^{-5} \mathrm{M}$ in Ar-saturated PhMe).

Table 1 Physical characterization of $\operatorname{Ir}(\text { TPSppy })_{3}$ and the reference $\operatorname{Ir}(\mathrm{ppy})_{3}$

\begin{tabular}{|c|c|c|c|c|c|}
\hline & Absorption wavelength/nm ${ }^{a}(\log \varepsilon)$ & Emission wavelength/nm ${ }^{b}$ & $E_{\mathrm{OX}} / \mathrm{V}^{c}$ & $E_{\mathrm{red}} / \mathrm{V}^{c}$ & $\overline{\Phi^{d}}$ \\
\hline $\operatorname{Ir}(\mathrm{pr}$ & 299 (4.08), $320(4.05), 408(3.41), 430$ (3.20) & 517,515 & $0.96^{e}, 1.41^{e}$ & $-0.71^{f}$ & 0.40 \\
\hline $\operatorname{Ir}(\text { TPSppy })_{3}$ & $296(4.98), 335(4.35), 395(4.23), 471(3.54)$ & 531,533 & $0.91^{e}, 1.43^{f}$ & $-0.64^{f}$ & 0.63 \\
\hline
\end{tabular}

${ }^{a} 1.0 \times 10^{-5} \mathrm{M}$ in Ar-saturated PhMe. ${ }^{b}$ Solution state, ${ }^{a}$ film state $\left(3 \mathrm{wt} \%\right.$ Ir(III) complex in PMMA). ${ }^{c}$ Determined by cyclic voltametry (vs. $\left.\mathrm{Ag}^{+} / \mathrm{Ag}\right) .{ }^{d}$ Relative phosphorescence quantum yield in solution state. ${ }^{a} e$ Reversible potential. ${ }^{f}$ Irreversible potential.

Table 2 Electroluminescent characteristics of polymer-based devices with $\operatorname{Ir}(\mathrm{TPSppy})_{3}$ and $\operatorname{Ir}(\mathrm{ppy})_{3}$

\begin{tabular}{|c|c|c|c|c|}
\hline $\begin{array}{l}\text { Doped ratio } \\
(\mathrm{wt} \%)\end{array}$ & $\begin{array}{l}\text { Operating voltage } / \mathrm{V} \\
\text { at } J^{a}=10 \mathrm{~mA} \mathrm{~cm}{ }^{-2}, \\
70 \mathrm{~mA} \mathrm{~cm}-2\end{array}$ & $\begin{array}{l}\text { Maximum } \\
\text { luminance/cd m }{ }^{-2} \\
\text { (corresponding } J \text { ) }\end{array}$ & $\begin{array}{l}\text { Maximum luminous } \\
\text { efficiency }\left(\eta_{1}\right) / \mathrm{cd} \mathrm{A}^{-1} \\
\text { (corresponding } J \text { ) }\end{array}$ & $\begin{array}{l}\text { Maximum power } \\
\text { efficiency }\left(\eta_{\mathrm{p}}\right) / \mathrm{lm} \mathrm{W}^{-1} \\
\text { (corresponding } J \text { ) }\end{array}$ \\
\hline 0.5 & $8.9,10.7$ & $2036(216.4)$ & $5.23(0.24)$ & $2.52(0.24)$ \\
\hline 4 & $10.3,12.0$ & $5665(71.4)$ & $29.4(0.061)$ & $15.4(0.061)$ \\
\hline 5 & $10.6,12.5$ & 9769 (168.7) & $25.6(0.023)$ & $13.4(0.023)$ \\
\hline 7 & $9.8,11.7$ & 7054 (88.7) & $30.8(0.047)$ & $17.6(0.047)$ \\
\hline 25 & $9.4,12.0$ & $21250(336.1)$ & $23.5(0.35)$ & $12.6(0.11)$ \\
\hline 30 & $9.2,11.9$ & $21250(355.9)$ & $19.0(1.58)$ & $10.1(0.15)$ \\
\hline $6^{b}$ & $10.4,12.5$ & $9432(147.6)$ & $26.4(0.17)$ & $12.7(0.17)$ \\
\hline
\end{tabular}




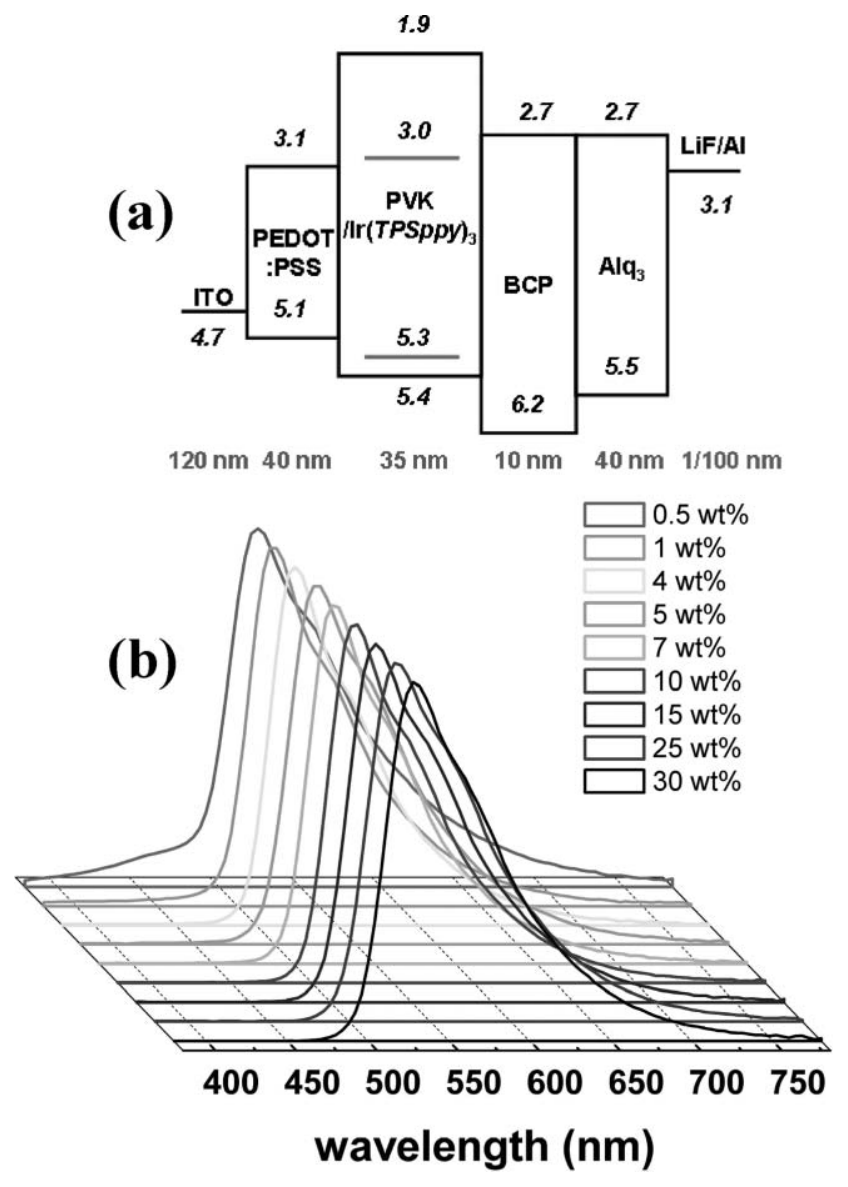

Fig. 3 (a) A configuration of the polymer-based OLED (numbers represent the energy value in $\mathrm{eV}$ units). (b) Normalized electroluminescence spectra of devices with different doping ratios ( $\mathrm{wt} \%$ relative to PVK) of $\operatorname{Ir}(\mathrm{TPSppy})_{3}$.

higher, indicating effective entrapment of excitons in the $\operatorname{Ir}(\text { TPSppy })_{3}$ in these devices.

The profiles of current density $\left(\mathrm{mA} \mathrm{cm}^{-2}\right)$ as a function of applied voltage [Fig. 4(a)] show that the turn on voltage of the device decreased with increasing doping ratio. If we consider the energy level of Ir(TPSppy) 3 [Fig. 3(a)], it is likely that the high doping ratio enables favorable balanced charge-transfer within the polymer layer; specifically, increase of the content of Ir(III) complex may facilitate transfer of the electron along the Ir(III) complex via a hopping mechanism. ${ }^{19}$

A maximum luminous efficiency of $32.8 \mathrm{~cd} \mathrm{~A}^{-1}$ was recorded at $5.5 \mathrm{~V}$ from the device with $10 \mathrm{wt} \% \operatorname{Ir}(\text { TPSppy })_{3}$ whereas that of $\operatorname{Ir}(\text { ppy })_{3}$ was $26.4 \mathrm{~cd} \mathrm{~A}^{-1}$ at $6.5 \mathrm{~V}$ from a device with $6 \mathrm{wt} \%$ doped ratio with an identical device configuration [see Fig. 4(c)]. [For Ir(ppy) $)_{3}$-based devices, only the best result (6 $\mathrm{wt}^{\%} \%$ ) is included.] In addition, the maximum power efficiency of the $\operatorname{Ir}(\text { TPSppy })_{3}$ device was $18.7 \mathrm{~lm} \mathrm{~W}^{-1}$, whereas that of the $\operatorname{Ir}(\mathrm{ppy})_{3}$ device was $10.9 \mathrm{~lm} \mathrm{~W}^{-1}$. If we consider that $\operatorname{Ir}(\text { TPSppy })_{3}$ has a higher molecular weight than $\operatorname{Ir}(\text { ppy })_{3}$ (1658.74 vs. 654.78, respectively), we find that the optimized doping ratio of $\operatorname{Ir}(\mathrm{TPSppy})_{3}(10 \mathrm{wt} \%)$ in fact corresponds to a smaller molar content than that of $\operatorname{Ir}(\mathrm{ppy})_{3}(6 \mathrm{wt} \%)$. Thus we can conclude that the higher efficiency of $\operatorname{Ir}(\text { TPSppy })_{3}$ compared to $\operatorname{Ir}(\text { ppy })_{3}$ is due to its inherent high phosphorescence quantum efficiency rather than simply to the 'site-isolation' under electrical excitation (i.e. triplet-triplet annihilation) provided by dendritic structures. As shown in Fig. 4(c), the maximum luminous efficiency for both $\operatorname{Ir}(\text { TPSppy })_{3}$ and $\operatorname{Ir}(\text { ppy })_{3}$ appears at low current density and drops slowly with increasing current density. However, the luminous efficiencies of $\operatorname{Ir}(\text { TPSppy })_{3}$-based devices are generally higher than those of $\operatorname{Ir}(\mathrm{ppy})_{3}$-based devices. Increasing the doping ratio of $\operatorname{Ir}($ TPSppy) 3 three-fold, from $10 \mathrm{wt} \%$ to $30 \mathrm{wt} \%$, caused the maximum luminous efficiency to change from $32.8 \mathrm{~cd} \mathrm{~A}^{-1}$ to $19.0 \mathrm{~cd} \mathrm{~A}^{-1}$, a decrease that was smaller than the decrease obtained by changing the doping ratio in the $\operatorname{Ir}(\text { ppy })_{3}$-based device. In fact, the luminous efficiency of $\operatorname{Ir}(\mathrm{ppy})_{3}$ showed a strong dependence on the doping ratio, decreasing from $26.4 \mathrm{~cd} \mathrm{~A}^{-1}$ to $15 \mathrm{~cd} \mathrm{~A}^{-1}$ when the doping ratio was increased 1.5-fold from $6 \mathrm{wt} \%$ for $9 \mathrm{wt} \% \operatorname{Ir}(p p y)_{3}$, and then sharply decreasing on further increase of the $\operatorname{Ir}(\mathrm{ppy})_{3}$ content. In addition, roll-off in luminous efficiency at high current density, most probably due to triplet-triplet annihilation, was significantly less for $\operatorname{Ir}(\text { TPSppy })_{3}$ than for $\operatorname{Ir}(p p y)_{3}$. The present results thus indicate that excited-state intermolecular interactions were suppressed even in the heavily doped system of $\operatorname{Ir}(\mathrm{TPSppy})_{3}$. It is worth noting that the luminous efficiency of the $\operatorname{Ir}(\text { TPSppy })_{3}$ device $\left(32.8 \mathrm{~cd} \mathrm{~A}^{-1}\right)$ is the highest value ever achieved among polymer-based OLEDs employing unblended (i.e. without electron transporting materials such as 2-(4-biphenylyl)-5-(4-tert-butylphenyl)-1,3,4-oxadiazole (PBD) or 1,3-bis(5-(4-tert-butylphenyl))-1,3,4-oxadiazole (OXD-7)) PVK as a host. ${ }^{24,25}$ Furthermore, considering that this luminous efficiency was achieved in a standard multilayered polymer device, our results indicate that Ir(TPSppy) ${ }_{3}$ outperforms previously reported $\operatorname{Ir}(\mathrm{III})$ complexes.

\section{Conclusions}

In summary, we successfully synthesized a new highly phosphorescent tris-cyclometalated homoleptic Ir(III) complex [Ir(TPSppy) $)_{3}$ ] with a silane-based dendritic substituent. The Ir(III) complex showed efficient phosphorescence of $74 \pm 3 \%$ absolute phosphorescent quantum yield in the solid state. The maximum luminous efficiency of polymer-based light emitting diodes employing $\operatorname{Ir}(\mathrm{TPSppy})_{3}$ reached $32.8 \mathrm{~cd} \mathrm{~A}^{-1}$, which was superior to that achieved using $\operatorname{Ir}(\mathrm{ppy})_{3}$ in a device with an identical configuration.

\section{Experimental}

\section{Synthesis of 4-bromo-triphenylsilylbenzene}

After a magnetically stirred solution of $p$-dibromobenzene $(24.0 \mathrm{~g}, 101 \mathrm{mmol})$ in anhydrous ether $(200 \mathrm{~mL})$ was cooled down to $-78{ }^{\circ} \mathrm{C}$, $64.9 \mathrm{~mL}$ of $n$-BuLi (1.6 $\mathrm{M}$ in hexane, $101 \mathrm{mmol}$ ) was added slowly under nitrogen. After $1 \mathrm{~h}$, the reaction mixture was warmed to room temperature and stirred for an additional $1 \mathrm{~h}$. Then, triphenylsilylchloride $(25.0 \mathrm{~g}$, $84.8 \mathrm{mmol}$ ) was delivered dropwise via syringe. After $2 \mathrm{~h}$, the solution was poured into $400 \mathrm{~mL}$ of water and the crude product was extracted with excess ether. Reprecipitation with THF and $\mathrm{MeOH}$ gave a white powder in $43 \%$ yield $(15.1 \mathrm{~g}$, $36.4 \mathrm{mmol}) .{ }^{1} \mathrm{H} \mathrm{NMR}\left(\mathrm{CDCl}_{3}, 500 \mathrm{MHz}\right): \delta 7.37(\mathrm{~m}, 6 \mathrm{H})$, 

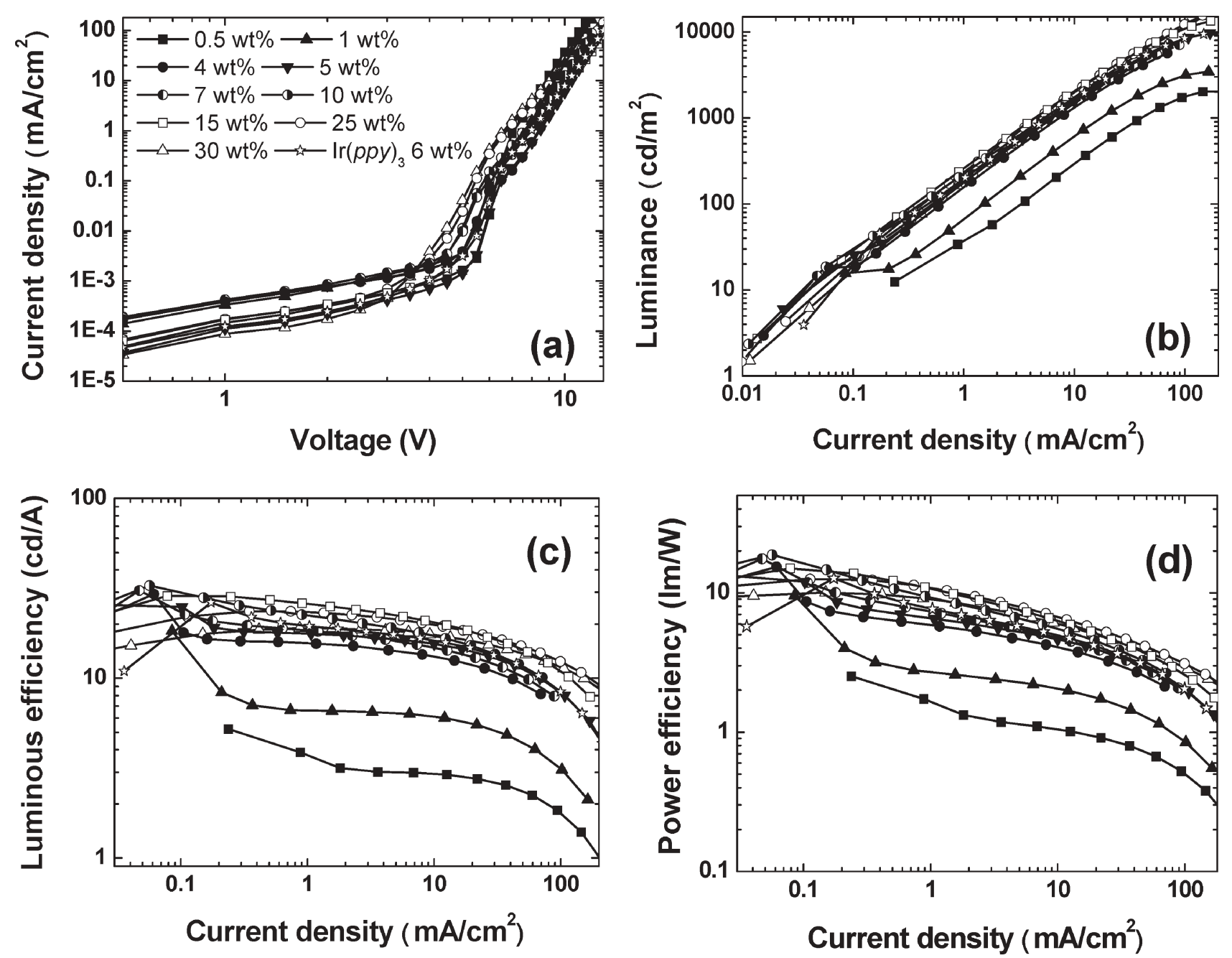

Fig. 4 Plots of (a) current density $\left(\mathrm{mA} \mathrm{cm}^{-2}\right)$ vs. voltage (V), (b) luminance ( $\mathrm{cd} \mathrm{m}^{-2}$ ), (c) luminous efficiency (cd $\left.\mathrm{A}^{-1}\right)$, and (d) power efficiency $\left(\mathrm{m} \mathrm{W}^{-1}\right) v$ s. current density $\left(\mathrm{mA} \mathrm{cm}^{-2}\right)$ of the fabricated devices.

$7.43(\mathrm{~m}, 3 \mathrm{H}), 7.50(\mathrm{~d}, J=8.0 \mathrm{~Hz}, 2 \mathrm{H}), 7.54(\mathrm{~d}, J=7.7 \mathrm{~Hz}, 6 \mathrm{H})$, $7.57(\mathrm{~d}, J=7.7 \mathrm{~Hz}, 2 \mathrm{H}) .{ }^{13} \mathrm{C} \mathrm{NMR}\left(\mathrm{CDCl}_{3}, 125 \mathrm{MHz}\right): \delta$ $128.1,128.2,129.5,129.8,131.3,136.5,136.6,138.1$.

Synthesis of 4-triphenylsilylphenylboronic acid

To a magnetically stirred solution of 4-bromo-triphenylsilylbenzene (13.7 g, $33.2 \mathrm{mmol})$ in $200 \mathrm{~mL}$ of anhydrous THF, $33.2 \mathrm{~mL}$ of $n$-BuLi (1.6 M in hexane, $53.1 \mathrm{mmol}$ ) was added via syringe under nitrogen at $-78{ }^{\circ} \mathrm{C}$. After stirring for $1 \mathrm{~h}, 10 \mathrm{~mL}$ (53.1 mmol) of trimethylborate was inserted to a reaction vessel slowly for $10 \mathrm{~min}$. Then the temperature of the reaction mixture was raised to room temperature, and stirring for an additional $2 \mathrm{~h}$ was carried out. Finally the reaction mixture was poured into $200 \mathrm{~mL}$ of water and acidified with aqueous $2 \mathrm{M} \mathrm{HCl}$. The crude product was extracted with EtOAc and purified by silica gel column chromatography ( $n$-hexane : EtOAc $=9: 1)$ to give a white powder in $40 \%$ yield $(5.1 \mathrm{~g}, 13.4 \mathrm{mmol}) .{ }^{1} \mathrm{H} \mathrm{NMR}\left(\mathrm{CDCl}_{3}\right.$, $300 \mathrm{MHz}): \delta 7.40(\mathrm{~m}, 11 \mathrm{H}), 7.57(\mathrm{~m}, 7 \mathrm{H}), 7.71(\mathrm{~d}, J=8.0 \mathrm{~Hz}$, $2 \mathrm{H}), 8.18(\mathrm{~d}, J=8.0 \mathrm{~Hz}, 1 \mathrm{H}) .{ }^{13} \mathrm{C} \mathrm{NMR}\left(\mathrm{CDCl}_{3}, 125 \mathrm{MHz}\right): \delta$ 128.2, 134.1, 134.9, 136.1, 136.6, 136.7, 140.1. GC-MS (EI) $\mathrm{m} / \mathrm{z}$ $380\left(\mathrm{M}^{+}\right)$, 249. Anal. Calcd for $\mathrm{C}_{24} \mathrm{H}_{21} \mathrm{BO}_{2} \mathrm{Si}: \mathrm{C}, 75.79 ; \mathrm{H}, 5.57$. Found: C, 75.76; H, 5.90\%

\section{Synthesis of 2-(3-bromophenyl)pyridine}

2-Iodopyridine (3.89 g, $19.0 \mathrm{mmol}$ ), 3-bromophenylboronic acid (3.81 g, $19.0 \mathrm{mmol})$, and tetrakis(triphenylphosphine)palla$\operatorname{dium}(0)(0.66 \mathrm{~g}, 0.57 \mathrm{mmol})$ were added to a round-bottomed flask equipped with a reflux condenser and dissolved in $200 \mathrm{~mL}$ of THF. After adding $100 \mathrm{~mL}$ of aqueous $2 \mathrm{M}$ sodium carbonate solution, the reaction mixture was heated at $80{ }^{\circ} \mathrm{C}$ for $1 \mathrm{~d}$. The cooled crude mixture was poured onto water and extracted with $\mathrm{CH}_{2} \mathrm{Cl}_{2}$ and dried over anhydrous magnesium sulfate. Finally, silica gel column purification ( $n$-hexane $:$ EtOAc $=5: 1)$ gave a sticky liquid $(3.43 \mathrm{~g}, 14.7 \mathrm{mmol})$ in $77 \%$ yield. ${ }^{1} \mathrm{H} \mathrm{NMR}\left(\mathrm{CDCl}_{3}\right.$, $300 \mathrm{MHz}): \delta 7.28(\mathrm{~m}, 4 \mathrm{H}), 7.73(\mathrm{~d}, J=7.1 \mathrm{~Hz}, 2 \mathrm{H}), 8.38(\mathrm{~m}, 2 \mathrm{H})$. ${ }^{13} \mathrm{C}$ NMR $\left(\mathrm{CDCl}_{3}, 125 \mathrm{MHz}\right): \delta 118.0,122.7,122.8,131.5$, 134.6, 134.7, 137.4, 141.0, 150.4, 155.2. Direct injection probe (DIP)-MS (FAB) $m / z 233\left(\mathrm{M}^{+}\right), 154$.

\section{Synthesis of the cyclometalating ligand 1}

The same procedure as for 2-(3-bromophenyl)pyridine was applied to give a yellow powder (1.12 g, $2.29 \mathrm{mmol})$ in $41 \%$ yield. ${ }^{1} \mathrm{H}$ NMR $\left(300 \mathrm{MHz}, \mathrm{CDCl}_{3}\right): \delta 7.25(\mathrm{~m}, 2 \mathrm{H}), 7.40(\mathrm{~m}$, $11 \mathrm{H}), 7.60(\mathrm{~m}, 6 \mathrm{H}), 7.68(\mathrm{~d}, J=8.3 \mathrm{~Hz}, 2 \mathrm{H}), 7.74(\mathrm{~m}, 2 \mathrm{H}), 7.99$ 
$(\mathrm{d}, J=6.5 \mathrm{~Hz}, 2 \mathrm{H}), 8.42(\mathrm{~s}, 1 \mathrm{H}), 8.70(\mathrm{td}, J=4.7 \mathrm{~Hz}, 1 \mathrm{H}) .{ }^{13} \mathrm{C}$ NMR $\left(\mathrm{CDCl}_{3}, 125 \mathrm{MHz}\right): \delta 121.0,122.5,126.5,128.0,128.1$, 129.7, 129.9, 134.3, 135.4, 136.6, 137.0, 137.1, 138.3, 140.7, 150.0, 157.6. DIP-MS (FAB) $m / z 489\left(\mathbf{M}^{+}\right), 414,336,259,154$. Anal. Calcd for $\mathrm{C}_{35} \mathrm{H}_{27} \mathrm{NSi}$ : C, 85.85; H, 5.56; N, 2.86. Found: C, 85.94; H, 5.64; N, 3.09\%

\section{Synthesis of $\mu$-chloride-Ir(III) dimer}

Literature procedure ${ }^{26}$ was applied (40\% yield). ${ }^{1} \mathrm{H}$ NMR $\left(500 \mathrm{MHz}, \mathrm{CDCl}_{3}\right): \delta 6.06(\mathrm{~s}, 4 \mathrm{H}), 6.25(\mathrm{t}, 4 \mathrm{H}), 6.95(\mathrm{~d}, J=$ $7.6 \mathrm{~Hz}, 4 \mathrm{H}), 7.18(\mathrm{~m}, 28 \mathrm{H}), 7.25(\mathrm{~m}, 28 \mathrm{H}), 7.31(\mathrm{t}, J=8.5 \mathrm{~Hz}$, 20H), 7.39 (d, $J=7.7 \mathrm{~Hz}, 6 \mathrm{H}), 7.59$ (d, $J=8.0 \mathrm{~Hz}, 6 \mathrm{H}), 9.00$ $(\mathrm{d}, J=5.5 \mathrm{~Hz}, 4 \mathrm{H}) \cdot{ }^{13} \mathrm{C} \mathrm{NMR}\left(\mathrm{CDCl}_{3}, 125 \mathrm{MHz}\right): \delta 118.5$, $122.3,122.8,126.5,127.7,128.1,129.2,129.3,134.8,136.1$, 136.6, 137.1, 138.7, 144.4, 145.2, 151.4, 168.0. HRMS (FAB) calculated $\mathrm{M}^{+}$1216.0509; observed $\mathrm{M}^{+}$1216.0499. Anal. Calcd for $\mathrm{C}_{140} \mathrm{H}_{104} \mathrm{Cl}_{2} \mathrm{Ir}_{2} \mathrm{~N}_{4} \mathrm{Si}_{4}$ : C, 69.77; H, 4.35; N, 2.32. Found: C, $69.61 ; \mathrm{H}, 4.64 ; \mathrm{N}, 2.46 \%$

\section{Synthesis of tris-cyclometalated Ir(III) complex [Ir(TPSppy) $\left.{ }_{3}\right]$}

Literature procedure ${ }^{26}$ was applied (48\% yield). ${ }^{1} \mathrm{H}$ NMR $\left(300 \mathrm{MHz}, \mathrm{CDCl}_{3}\right): \delta 6.90-7.02(\mathrm{~m}, 16 \mathrm{H}), 7.07-7.23(\mathrm{~m}, 17 \mathrm{H})$, 7.32-7.43 (m, 21H), 7.51-7.68 (m, 20H), 7.78-7.92 (m, 4H). ${ }^{13} \mathrm{C}$ NMR $\left(\mathrm{CDCl}_{3}, 125 \mathrm{MHz}\right): \delta 119.0,120.0,122.1,124.1$, 130.1, 136.1, 137.3, 143.9, 147.3, 161.4, 167.0. DIP-MS (FAB) $\mathrm{m} / \mathrm{z} 1658\left(\mathrm{M}^{+}\right), 1581,1506,1430,1093,1017,259$. Anal. Calcd for $\mathrm{C}_{105} \mathrm{H}_{78} \mathrm{IrN}_{3} \mathrm{Si}_{3}$ : C, 76.05; H, 4.74; N, 2.53. Found: C, $76.08 ; \mathrm{H}, 5.01 ; \mathrm{N}, 2.67 \%$

\section{Characterization and device fabrication}

Absorption spectra of solutions $\left(1.0 \times 10^{-5} \mathrm{M}\right.$ in PhMe $)$ were recorded with SHIMADZU UV-1650PC from 280 to $700 \mathrm{~nm}$. Photoluminescence (PL) spectra were obtained with a SHIMADZU RF-5301PC spectrophotometer in the range of ca. 400-700 nm. Absorption and PL spectra of $\operatorname{Ir}(\mathrm{III})$ complexes in solution were measured after Ar-saturation. Absolute phosphorescence quantum yields (PLQY) were measured in a system comprising a 6 in integrated sphere. An excitation beam of $325 \mathrm{~nm}$ from $\mathrm{He}$ : Cd CW laser was loosely focused on the sample, and the emission light was spectrally resolved by using a $30 \mathrm{~cm}$ monochromator (Acton) after passing through the sample. The light signal was detected via a photomultiplier tube. Cyclic voltametric experiments were carried out with a model 273A (Princeton Applied Research) using three electrode cell assemblies comprising a quasi $\mathrm{Ag}$ wire as a reference electrode and $\mathrm{Pt}$ as counter and working electrodes. Measurements were carried out in Arsaturated dichloromethane solution with tetrabutylammonium tetrafluoroborate $(5 \mathrm{mM})$ as a supporting electrolyte at a scan rate of $50 \mathrm{mV} \mathrm{s}^{-1}$. Each potential was calibrated with ferrocene as a reference. Dmol $^{3}$ module installed within Materials Studio (Accelrys) was used for DFT calculations. Ground state geometry optimization and single point calculation were done with BLYP functional and DNP basis sets under effective core potential. SCF tolerance was maintained within $10^{-6}$. For device fabrication, PEDOT : PSS (Baytron P VP Al 4083 purchased from H. C. Starck) was spin-coated onto pre-cleaned and UV-O $\mathrm{O}_{3}$ treated ITO (Asahi) substrates, yielding layers with a thickness of $c a .40 \mathrm{~nm}$, then baked at $200{ }^{\circ} \mathrm{C}$ for $10 \mathrm{~min}$ to remove residual water. PVK (Kanto Chem. Corp.) doped with dyes was spin-coated onto the PEDOT : PSS layer resulting in a layer $c a .35 \mathrm{~nm}$ thickness. All of the polymer layers were fabricated in Ar-atmosphere. Small molecules and metals were thermally evaporated at $10^{-7}$ Torr. Finally, devices were encapsulated in a glove box with a glass cap. Current-density-voltage characteristics were measured with a Keithley 2400 source meter. The brightness and electroluminscence spectra of the devices were measured with SpectraColorimeter PR-650.

\section{Acknowledgements}

This work was supported in parts by the Ministry of Science and Technology of Korea through a National Research Laboratory (NRL) program awarded to Prof. Soo Young Park and by Dongwoo FineChem Co., Ltd. Prof. J.-J Kim acknowledges the Ministry of Commerce, Industry and Energy of Korea through the OLED center, Center for Electro- and Photo-Responsive Molecules, and Samsung SDI Corporation for financial support.

\section{References}

1 M. A. Baldo, D. F. O'Brian, Y. You, A. Shoustikov, S. Sibley, M. E. Thompson and S. R. Forrest, Nature, 1998, 395, 151.

2 M. A. Baldo, M. E. Thompson and S. R. Forrest, Nature, 2000, 403, 750.

3 M. A. Baldo, S. Lamansky, P. E. Burrows, M. E. Thompson and S. R. Forrest, Appl. Phys. Lett., 1999, 75, 4.

4 M. Ikai, S. Tokito, Y. Sakamoto, T. Suzuki and Y. Taga, Appl. Phys. Lett., 2001, 79, 156.

5 F. C. Chen, Y. Yang, M. E. Thompson and J. Kido, Appl. Phys. Lett., 2002, 80, 2308.

6 M. K. Nazeeruddin, R. Humphry-Baker, D. Berner, S. Rivier, L. Zuppiroli and M. Graetzel, J. Am. Chem. Soc., 2003, 125, 8790.

7 Y. You, S. H. Kim, H. K. Jung and S. Y. Park, Macromolecules, 2006, 39, 349

8 M. A. Baldo, C. Adachi and S. R. Forrest, Phys. Rev. B, 2000, 62, 10967.

9 B. D'Andrade, J. Brooks, V. Adamovich, M. E. Thompson and S. R. Forrest, Adv. Mater., 2002, 14, 1032.

10 M. Halim, J. N. G. Pillow, I. D. W. Samuel and P. L. Burn, Adv. Mater., 1999, 11, 371.

11 A. W. Freeman, S. C. Koene, P. R. L. Malenfant, M. E. Thompson and J. M. J. Frechet, J. Am. Chem. Soc., 2000, 122, 12385.

12 E. B. Namdas, A. Ruseckas, I. D. W. Samuel, S.-C. Lo and P. L. Burn, J. Phys. Chem. B, 2004, 108, 1570.

13 S.-C. Lo, N. A. H. Male, J. P. J. Markham, S. W. Magennis, P. L. Burn, O. V. Salata and I. D. W. Samuel, Adv. Mater., 2002, 14, 975.

14 S.-C. Lo, G. J. Richards, J. P. J. Markham, E. B. Namdas, S. Sharma, P. L. Burn and I. D. W. Samuel, Adv. Funct. Mater., 2005, 15, 1451 .

15 T. D. Anthopoulos, M. J. Frampton, E. B. Namdas, P. L. Burn and I. D. W. Samuel, Adv. Mater., 2004, 16, 557.

16 H. Z. Xie, M. W. Liu, O. Y. Wang, X. H. Zhang, C. S. Lee, L. S. Hung, S. T. Lee, P. F. Teng, H. L. Kwong, H. Zheng and C. M. Che, Adv. Mater., 2001, 13, 1245.

17 S.-C. Lo, T. D. Anthopoulos, E. B. Namdas, P. L. Burn and I. D. W. Samuel, Adv. Mater., 2005, 17, 1945.

18 R. J. Holmes, S. R. Forrest, T. Sajoto, A. Tamayo, P. I. Djurovich, M. E. Thompson, J. Brooks, Y.-J. Tung, B. W. D'Andrade, M. S. Weaver, R. C. Kwong and J. J. Brown, Appl. Phys. Lett., 2005, 87, 243507.

19 X. Ren, J. Li, R. J. Holmes, P. I. Djurovich, S. R. Forrest and M. E. Thompson, Chem. Mater., 2004, 16, 4743. 
20 X.-M. Liu, J. Xu, X. Lu and C. He, Org. Lett., 2005, 7, 2829.

21 Y.-Y. Noh, C.-L. Lee and J.-J. Kim, J. Chem. Phys., 2003, 118 2853.

22 A. P. Wilde, K. A. King and R. J. Watts, J. Phys. Chem., 1991, 95, 629

23 Y. Wang, F. Teng, Z. Xu, Y. Hou, Y. Wang and X. Xu, Eur. Polym. J., 2005, 41, 1020.
24 X. Gong, J. C. Ostrowski, G. C. Bazan, D. Moses, A. J. Heeger, M. S. Liu and A. K. Y. Jen, Adv. Mater., 2003, 15, 45.

25 Y. Kawamura, S. Yanagida and S. R. Forrest, J. Appl. Phys., 2002, 92, 87.

26 A. B. Tamayo, B. D. Alleyne, P. I. Djurovich, S. Lamansky, I. Tsyba, N. H. Ho, R. Bau and M. E. Thompson, J. Am. Chem. Soc., 2003, 125, 7377.

\section{Find a SOLUTION ... with books from the RSC}

Choose from exciting textbooks, research level books or reference books in a wide range of subject areas, including:

- Biological science

- Food and nutrition

- Materials and nanoscience

- Analytical and environmental sciences

- Organic, inorganic and physical chemistry

\section{Look out for $\mathbf{3}$ new series coming soon ...}

- RSC Nanoscience \& Nanotechnology Series

- Issues in Toxicology

- RSC Biomolecular Sciences Series
NANOCHEMISTRY

A Chemical Approach to Nanomatereidis

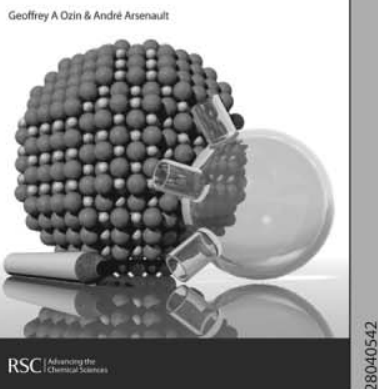

